\title{
Pelatihan Pembuatan Minyak Telon Antinyamuk Sebagai Upaya Perawatan Kesehatan Anak dan Perintisan Home Industri di Surakarta
}

\author{
Ghani Nurfiana Fadma Sari, Endang Sri Rejeki, Mamik Ponco Rahayu, \\ Nuraini Harmastuti, Taufik Turahman, Supriyadi \\ Universitas Setia Budi Surakarta \\ ghani.nurfiana@rocketmail.com
}

Received: $21^{\text {st }}$ June 2020 | Accepted: $1^{\text {st }}$ December 2020 | Published: 30 $30^{\text {th }}$ January 2021

\section{Key word:}

Training;

Telon oil;

anti-mosquito;

essential oils

\section{Kata Kunci}

Pelatihan;

minyak telon; anti nyamuk; minyak essensial

\section{Abstract}

Telon oil and children have been an inseparable unity. The making of telon oil from easy-to-find traditional ingredients can encourage home industry ideas for economic growth. The use of essential oils (orange oil/ lavender oil) as components of the making of telon oil is expected to avoid mosquito bites causing itching and even dengue fever. The community service activity program aims to provide training of anti-mosquito telon oil making to keep children healthy. The participants of the program include a cadre of PKK (Family Welfare Movement) members in RW (Community Unit) 21, Nusukan Village, Banjarsari Sub-district, Surakarta. The community service activity began with the explanation of natural ingredients used to make telon oil as well as their benefits. Afterward, the training was conducted through several stages including a tutorial, technical assistance by the community service team, and evaluation of the activity. The results of the activity are: 1) the participants have an understanding of the benefits of the ingredients used; 2) the participants understand the procedure to make the anti-mosquito telon oil; 3) the participants can make the anti-mosquito telon oil by themselves.

\section{Abstrak}

Minyak telon dan anak-anak sudah seperti suatu kesatuan yang rasanya tidak bisa dipisahkan. Pembuatan minyak telon dari bahan tradisional yang mudah didapatkan dapat menciptakan motivasi perintisan home indutri dalam upaya peningkatan perekonomian warga. Pemanfaatan minyak esensial (minyak jeruk/minyak lavender) sebagai komponen dalam pembuatan minyak telon diharapkan dapat mencegah dari gigitan nyamuk yang bisa menyebabkan gatal-gatal dikulit hingga demam berdarah. Tujuan dari program kegiatan pengabdian masyarakat ini adalah memberikan pelatihan pembuatan minyak telon antinyamuk untuk perawatan kesehatan anak kepada kader PKK di lingkungan RW 21 Kelurahan Nusukan Kecamatan Banjarsari, Surakarta. Kegiatan pengabdian diawali dengan penjelasan tentang bahan-bahan alami yang digunakan dalam pembuatan minyak telon dan khasiat dari bahan tersebut. Selanjutnya pelatihan pembuatan minyak telon kepada para kader PKK. Kegiatan pelatihan dibagi dalam beberapa tahapan dimulai dari tutorial kemudian dilanjutkan dengan pendampingan dari tim pengabdian dan diakhiri dengan evaluasi pelaksanaan kegiatan. Hasil dari kegiatan ini adalah 1) Peserta memiliki pemahaman tentang khasiat dari masing-masing bahan yang dipakai untuk pembuatan minyak telon; 2) Peserta memahami prosedur pembuatan minyak telon antinyamuk; 3) Peserta dapat membuat minyak telon anti nyamuk. 


\section{PENDAHULUAN}

Minyak telon adalah campuran 3 macam minyak. Kata telon berasal dari Bahasa Jawa yang berarti telu atai tiga. Minyak telon merupakan paduan dari minyak adas (Oleum Foeniculi), minyak Kayu Putih (Oleum Cajuputi) dan minyak kelapa (Oleum Cocos) dengan perbandingan tertentu. Ketiganya mempunyai fungsi yang berbeda dan khasiatnya bersinergi satu dengan yang lain. Minyak telon bermanfaat untuk mencegah dan mengobati perut kembung pada bayi dan memberikan rasa hangat pada bayi. Selain itu minyak telon dapat meringankan gejala kolik-mulas pada bayi (Solarbesain, 2019).

Komposisi masing-masing minyak dalam minyak telon biasanya adalah 3:3:4. Minyak kelapa berfungsi sebagai pembawa atau pelarut. Saat ini beberapa produsen minyak telon ada yang memproduksi minyak telon dengan komposisi yang berbeda misalkan 1:1:3 ataupun menambah minyak lain sebagai campuran seperti minyak esensial lavender bahkan ada yang mengganti minyak kelapa dengan minyak zaitun (Olive Oil). Namun tentunya kalau sudah ditambahkan minyak lain diluar formula yang telah dikenal turun temurun manfaatnya akan berbeda dan aroma khas minyak telon tak tercium lagi. (Rusli, 2010)

Buah adas mengandung 2-6\% minyak atsiri (terdiri dari 50-70\% transanetol, lebih kurang $20 \%$ cis-anetol) 0,3\%; $15-24 \%$ fenkon (fenkon berasa pahit dan mempunyai aroma seperti kamfer). Disamping itu buah adas mengandung pula metilkavikol 4-7\%, anisaldehid (suatu hasil oksidasi anetol), beberapa senyawa terpenoid hidrokarbon (pinen, felandren dan limonen), funikulin, dan terpineol. Selain kandungan minyak atsiri, dalam buah adas terdapat pula funikulosida, suatu stilbeneglikosida, minyak lemak, protein, asam-asam organik dan flavonoid (Sudarsono et al., 2002).

Minyak kayu putih (oleum cajeputi) dihasilkan dari hasil penyulingan daun dan ranting kayu putih. Minyak ini mengandung terutama eukaliptol (1,8-cineol) (komponen paling banyak, sekitar 60\%), $\alpha$-terpineol dan ester asetatnya, $\alpha$-pinen, dan limonene (SNI, 2006).

Virgin coconut oil (VCO) yaitu minyak yang diperoleh dari daging buah kelapa tua yang segar dan diproses dengan diperas, dengan atau tanpa penambahan air, tanpa pemanasan atau pemanasan tidak lebih dari $60^{\circ} \mathrm{C}$ dan aman dikonsumsi manusia. (SNI, 2008). Daging buah kelapa segar sebagai bahan baku VCO memiliki kandungan minyak $34,7 \%$, protein $3,8 \%$, air 
46,9\% dan karbohidrat 14,6\%, sedangkan komponen VCO sendiri berupa asam lemak jenuh sekitar 90\% dan asam lemak tak jenuh sekitar 10\%. Asam lemak jenuh VCO didominasi oleh asam laurat. VCO mengandung $\pm 51,24 \%$ asam laurat dan sekitar 7,91\% asam kaprilat. Keduanya merupakan asam lemak rantai sedang yang biasa disebut Medium Chain Fatty Acid (MCFA) (Sutarmi dan Hartin, 2005)

Desa Bibis Luhur RW 21 Kelurahan Nusukan Surakarta mempunyai mata pencaharian yang beragam, sebagian besar adalah wiraswasta dan ibu rumah tangga. Banyaknya perkumpulan PKK di wilayah tersebut dan kurangnya pengetahuan tentang pembuatan minyak telon, maka perlu dilakukan transfer ilmu dari tim pengabdian Universitas Setia Budi dalam bentuk penyuluhan dan pelatihan pembuatan minyak telon kepada masyarakat untuk meningkatkan ketrampilan dan motivasi dalam menciptakan peluang usaha rumahan (home industri) dengan produk produk yang dapat dilakukan dengan mudah yang sekaligus menambah income penduduk.

Tujuan dilaksanakannya kegiatan pengabdian masyarakat ini adalah untuk : meningkatkan pengetahuan tentang khasiat dari masing-masing bahan dalam proses pembuatan minyak telon pada kader PKK, meningkatkan keterampilan untuk membuat minyak telon secara mandiri pada kader PKK di desa Bibis Luhur RW 21 Nusukan Surakarta.

\section{METODE}

Sasaran Kegiatan Pengabdian Masyarakat yaitu Kader PKK RW 21, Kelurahan Nusukan, Kecamatan Banjarsari, Kota Surakarta yang berpartisipasi sebagai peserta penyuluhan dan pelatihan pembuatan produk minyak telon anti nyamuk.

Metode kegiatan pengabdian yang dilakukan, yaitu:

1. Ceramah dan Diskusi

Metode ceramah yang dikombinasikan dengan membagikan leaflet yang digunakan untuk menyampaikan materi tentang: manfaat minyak telon, khasiat bahan-bahan yang digunakan secara ilmiah, formula minyak telon dan cara pembuatan. Penggunaan metode ini dapat memberikan materi relatif banyak secara padat, cepat, dan mudah.

2. Demonstrasi

Metode demonstrasi digunakan untuk menunjukkan suatu proses kerja sehingga memberikan kemudahan bagi peserta pengabdian. Demonstrasi dilakukan oleh tim pengabdian sebagai nara sumber untuk menyampaikan atau mempraktekkan pembuatan minyak telon yang benar. 
Adapun langkah-langkah kegiatan ini melalui tahapan sebagai berikut:

1. Persiapan, merupakan perencanaan program pengabdian yang meliputi: koordinasi dengan pihak desa lokasi pengabdian, penetapan waktu pelatihan, penentuan sasaran dan target peserta pelatihan, dan perencanaan materi pelatihan.

2. Pelaksanaan, untuk meningkatkan pengetahuan ibu rumah tangga tentang manfaat minyak telon, khasiat bahanbahan yang digunakan secara ilmiah, formula minyak telon dan cara pembuatan serta meningkatkan keterampilan dalam membuat minyak telon melalui kegiatan pelatihan. Pelatihan dilakukan oleh tim pengabdian untuk penyamaan persepsi dengan peserta. Pelatihan dilakukan dengan penyediaan sarana dan prasarana kegiatan pengabdian dalam upaya peningkatan pengetahuan dan keterampilan ibu rumah tangga.

3. Pembagian minyak telon yang sudah dibuat. Pembagian minyak telon ini dilakukan untuk merealisasikan pemanfaatan pemanfaatan minyak kelapa, minyak adas dan minyak kayu putih dan pemantauan/follow-up penggunaannya. Diharapkan dengan adanya kegiatan ini, minat masyarakat semakin kreatif dalam membuat minyak telon secara mandiri.

\section{HASIL}

Kegiatan pengabdian masyarakat ini diawali dengan dilakukannya tahap observasi dan koordinasi dengan ketua RW 21 kelurahan Nusukan dan ketua kader PKK RW 21 kelurahan Nusukan. Observasi dilakukan untuk mengetahui permasalahan yang dihadapi oleh kader PKK RW 21 kelurahan Nusukan dan koordinasi membahas solusi dan program pengabdian yang akan dilaksanakan serta waktu pelaksanaan kegiatan. Keberhasilan target jumlah peserta pengabdian dapat dikatakan sangat baik. Dari 30 orang peserta yang diundang, semuanya $(100 \%)$ dapat menghadiri kegiatan penyuluhan dan pelatihan pembuatan minyak telon anti nyamuk.

Penyuluhan mengenai manfaat minyak telon dan komposisi pembuatannya dilakukan pada tanggal 14 November 2019 yang bertepatan dengan rapat kader PKK RW 21 kelurahan Nusukan yang dihadiri oleh perwakilan setiap pengurus RT di RW 21. Kegiatan ini memberikan penyuluhan mengenai manfaat minyak telon, bahanbahan yang digunakan dan khasiatnya,dan proses pembuatannya Setelah itu dilanjutkan dengan tutorial secara langsung tentang pembuatan minyak telon dengan 
tambahan minyak lavender/citrus sebagai anti nyamuk serta dilakukan monitoring dan evaluasi terhadap hasil pelatihan.
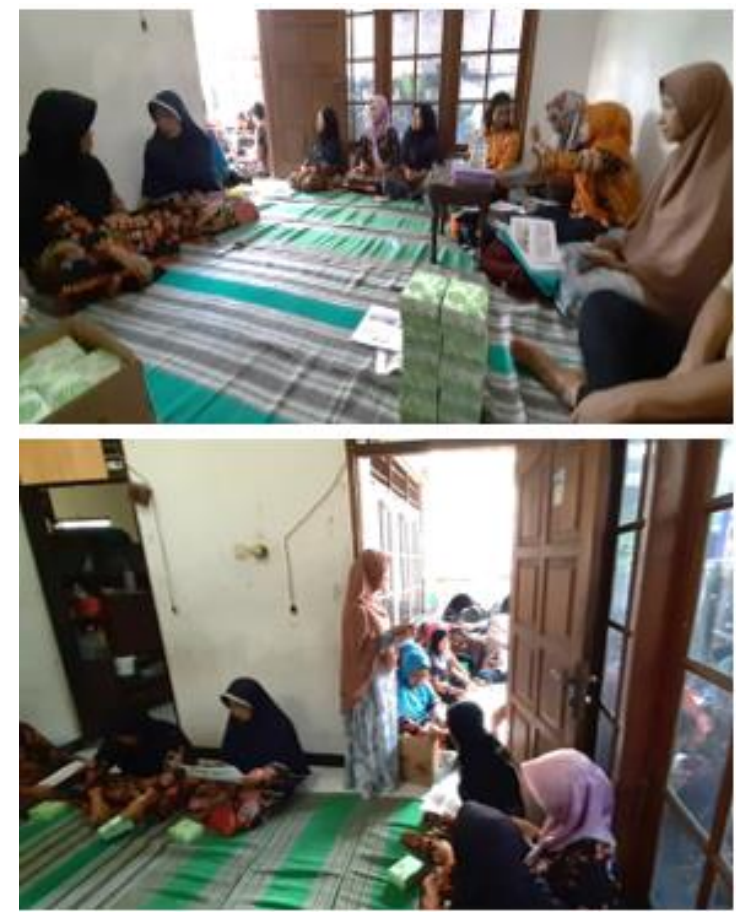

Gambar 1. Penyuluhan manfaat minyak telon dan cara pembuatannya

\section{PEMBAHASAN}

Kegiatan pengabdian yang telah dilakukan dapat diterima oleh peserta dan dinilai sangat bermanfaat bagi warga para kader PKK khususnya di lingkungan RW 21 Kelurahan Nusukan kecamatan Banjarsari Surakarta. Penyuluhan yang telah dilakukan terlihat antusisme kader PKK cukup tinggi yang ditandai dengan banyaknya pertanyaan selama sesi penyuluhan. Pada tahap penyuluhan ini diberikan juga materi dalam bentuk leafleat yang dibagikan ke kader PKK. Selanjutnya pelatihan pembuatan minyak telon dilakukan dengan cara mendemostrasikan secara langsung sehingga dapat ditiru oleh masyarakat.

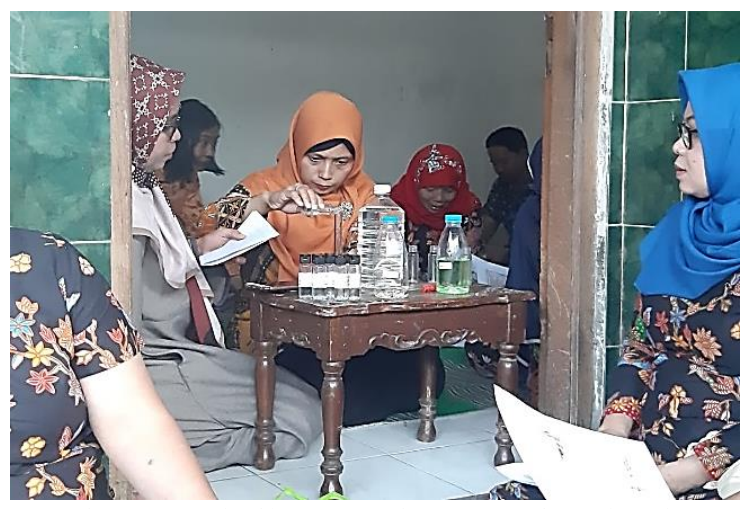

Gambar 2. Pelatihan pembuatan minyak telon

Cara pembuatan minyak telon antara lain : (1) Ambil minyak adas $(20 \mathrm{ml})$, minyak kelapa (15 ml), minyak kayu putih (22 $\mathrm{ml})$ dan minyak lavender $(3 \mathrm{ml})$ menggunakan pipet tetes; (2) Masukkan masing-masing minyak kedalam gelas ukur $100 \mathrm{ml}$; (3) Campur dan kocok hingga homogen; (4) Tuangkan kedalam botol kecil (5) Minyak telon anti nyamuk siap dipakai.

Pada tahap kegiatan ini peserta dilatih untuk dapat melakukan pembuatan minyak telon secara mendiri, dengan pengawasan dan arahan dari tim pengabdian sehingga peserta memiliki kemampuan dan pemahaman untuk dapat membuat minyak telon sendiri di rumah masing-masing. Selain itu ketrampilan ini dapat dikembangkan menjadi usaha mandiri keluarga. Antusiasme peserta cukup tinggi pada tahap kegiatan ini ditandai dengan banyaknya pertanyaan dan keikutsertaan kader PKK dalam pelatihan pembuatan minyak telon 


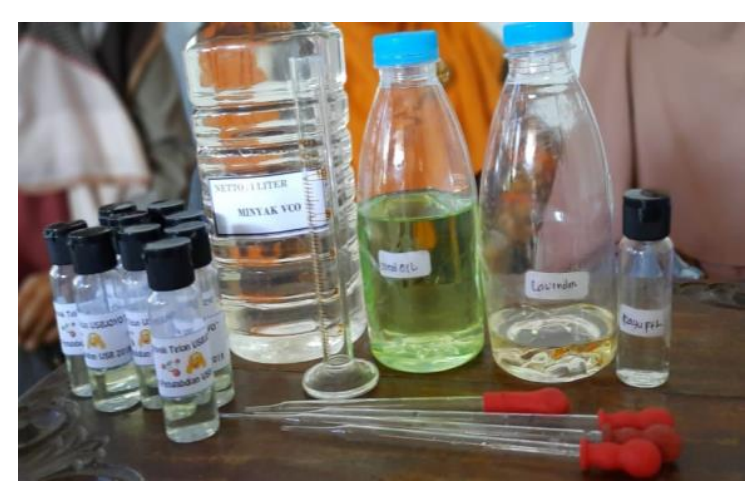

Gambar 3. Hasil jadi minyak telon anti nyamuk

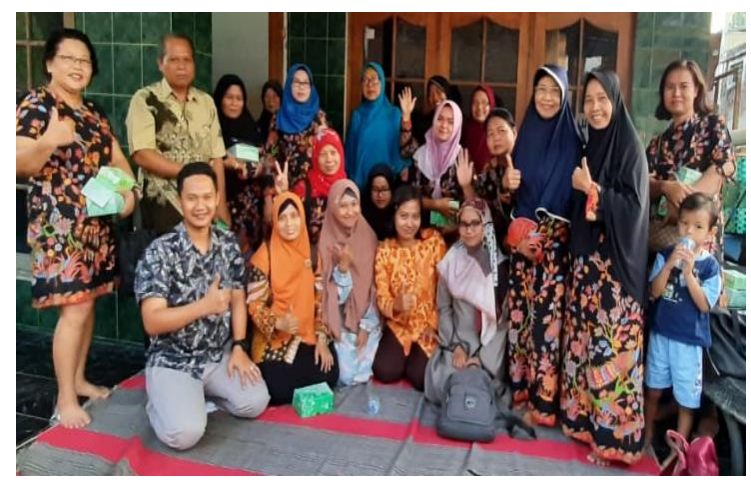

Gambar 4. Foto bersama dengan kader PKK

\section{SIMPULAN}

Kegiatan pelatihan pembuatan minyak telon anti nyamuk yang telah dilaksanakan di lingkungan Tegal Mulyo, Nusukan, Banjarsari Surakarta bermanfaat bagi masyarakat khususnya kader PKK sehingga diharapkan dapat meningkatkan ketrampilan dalam pembuatan minyak telon sebagai upaya perawatan kesehatan anak dan dapat menciptakan motivasi perintisan home indutri dalam upaya peningkatan perekonomian warga.

\section{SARAN}

Peningkatan kapabilitas anggota PKK dapat dilanjutkan dengan pengabdian lanjutan dengan materi kemasan dan desain merk untuk minyak telon anti nyamuk dan pemasarannya.

\section{UCAPAN TERIMA KASIH}

Tim pengabdian menyampaikan terima kasih kepada kepala kelurahan Nusukan Banjarsari Surakarta yang telah memberikan perijinan serta masyarakat khususnya kader PKK di wilayah Bibis Luhur Nusukan yang telah berpartisipasi pada kegiatan pengabdian ini.

\section{DAFTAR PUSTAKA}

Badan Standardisasi Nasional. (2006). SNI 06-3954-2006. Minyak Kelapa Virgin (VCO). Jakarta : Badan Standardisasi Nasional

Badan Standardisasi Nasional. (2008). SNI 7381-2008. Minyak Kayu Putih. Jakarta : Badan Standardisasi Nasional Rusli, M.S. (2010). Sukses Memproduksi Minyak Atsiri. AgroMedia.

Solarbesain Frengky \& Pidjihastuti Isti. (2019). Pengaruh Komposisi Pada Minyak Telon Terhadap Uji Indeks Bias Dengan Menggunakan Refraktometer Tipe Way Abbe. Media Komunikasi Rekayasa Proses dan Teknologi Tepat Guna, Vol. 15(1):3236.

Sudarsono, P.N., Gunawan, D., Wahyuono, S. \& Donatus, I.A. (2002). Tumbuhan 
Ghani Nurfiana Fadma Sari, Endang Sri

Rejeki, Mamik Ponco Rahayu, Nuraini

Harmastuti, Taufik Turahman, Supriyadi

Obat II (Hasil penelitian, Sifat-sifat

dan Penggunaan). PPOT UGM,

Yogyakarta. 89-90

Sutarmi \& Rozaline, H. (2005). Taklukkan

Penyakit dengan VCO Virgin Coconut

Oil. Jakarta: Penebar Swadaya. 